\title{
Carbon-based materials prepared from pine gasification residues for acetaminophen adsorption
}

\author{
Margarida Galhetas $^{\mathrm{a}, \mathrm{b}}$, Ana S. Mestre ${ }^{\mathrm{a}}$, Moisés L. Pinto ${ }^{\mathrm{c}}$, Ibrahim Gulyurtlu ${ }^{\mathrm{b}}$, Helena Lopes ${ }^{\mathrm{b}}$, \\ Ana P. Carvalho ${ }^{\mathrm{a}, *}$ \\ a Departamento de Química e Bioquímica and CQB, Faculdade de Ciências da Universidade de Lisboa, Ed. C8, Campo Grande, 1749-016 Lisboa, Portugal \\ ${ }^{\mathrm{b}}$ LNEG, Estrada do Paço do Lumiar 22, 1749-032 Lisboa, Portugal \\ ' Departamento de Química, CICECO, Universidade de Aveiro, 3810-193 Aveiro, Portugal
}

\section{H I G H L I G H T S}

- Fly ash from pine gasification was used as precursor of carbon-based materials.

- Materials with $A_{\mathrm{BET}}$ of $1171 \mathrm{~m}^{2} \mathrm{~g}^{-1}$ were obtain by chemical activation with $\mathrm{K}_{2} \mathrm{CO}_{3}$.

- The solids were tested for the removal of acetaminophen from aqueous solution.

- Molecular dimensions of monomer and dimer were considered in the discussion.

- The affinity of paracetamol for the carbon is maximized by pores with width of $0.7 \mathrm{~nm}$.

\section{A R T I C L E I N F O}

\section{Article history:}

Received 2 October 2013

Received in revised form 22 November 2013

Accepted 25 November 2013

Available online 4 December 2013

\section{Keywords:}

Pine gasification

Fly ash

Carbon materials

Micropore size distribution

Acetaminophen adsorption
G R A P H I C A L A B S T R A C T

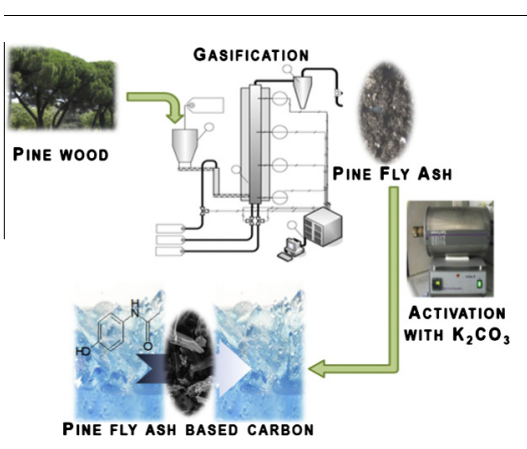

\begin{abstract}
A B S T R A C T
Fly ash, a residue produced from pine gasification, was used as precursor of carbon-based materials assayed in acetaminophen adsorption. Materials prepared by activation with $\mathrm{K}_{2} \mathrm{CO}_{3}$, presented high porosity development $\left(A_{\mathrm{BET}} \approx 1200 \mathrm{~m}^{2} \mathrm{~g}^{-1}\right)$ and samples calcined at $900{ }^{\circ} \mathrm{C}$ presented high volumes of large micropores and mesopores. Kinetic and equilibrium acetaminophen adsorption data showed that the process obeys to the pseudo-second order kinetic equation and Langmuir model, respectively. The rate of acetaminophen adsorption depends of the presence of larger micropores. For the lab-made samples monolayer adsorption capacities attained values similar to those of commercial carbons. The influence of the micropore size distribution of the carbons in the acetaminophen adsorption process justified the lower adsorption affinities of the lab-made carbons. The importance of pores of a specific dimension $(0.7 \mathrm{~nm})$ to enhance the affinity of the molecule towards the carbon surface was demonstrated. The increase of temperature lead to higher monolayer adsorption capacities, most likely due to the easier accessibility of the acetaminophen species to the narrowest micropores.
\end{abstract}

(c) 2013 Elsevier B.V. All rights reserved.

\section{Introduction}

In the industrialized countries energy production is, to a large extent, based on fossil fuels, which leads to the release of greenhouse gases into the atmosphere, causing serious and well known environmental problems. In this context, energy production through biomass gasification is nowadays considered a low carbon emission technology being an alternative to combustion, since it is,

\footnotetext{
* Corresponding author. Tel.: +351 217500897; fax: +351 217500888.

E-mail addresses: amgalhetas@fc.ul.pt (M. Galhetas), asmestre@fc.ul.pt (A.S. Mestre), moises.pinto@ua.pt (M.L. Pinto), ibrahim.gulyurtlu@lneg.pt (I. Gulyurtlu), helena.lopes@lneg.pt (H. Lopes), ana.carvalho@fc.ul.pt (A.P. Carvalho).
} 